\title{
Determination of microbiological and chemical characteristics of kefir consumed in Bursa
}

\author{
Figen CETINKAYA, Tulay ELAL MUS
}

University of Uludag, Faculty of Veterinary Medicine, Department of Food Hygiene and Technology, Gorukle-Bursa, Turkey.

\begin{abstract}
Summary: This study was conducted to determine of microbiological quality and some chemical characteristics of 50 kefir samples purchased from different retail markets in Bursa province. In the samples investigated, the mean numbers of lactobacilli, lactococci, enterococci, Enterobacteriacea, Staphylococcus aureus and yeast were determined as $3.6 \times 10^{7} \mathrm{cfu} / \mathrm{ml}, 1.8 \times 10^{8} \mathrm{cfu} / \mathrm{ml}$, $4.8 \times 10^{4} \mathrm{cfu} / \mathrm{ml}, 7.3 \times 10^{3} \mathrm{cfu} / \mathrm{ml}, 2.4 \times 10^{2} \mathrm{cfu} / \mathrm{ml}$ and $7.7 \times 10^{4} \mathrm{cfu} / \mathrm{ml}$, respectively. 26 of $50 \mathrm{kefir}$ samples were found to have $<0.30$ $\mathrm{MPN} / \mathrm{ml}$ of total coliform while 5 samples had numbers of $>110 \mathrm{MPN} / \mathrm{ml}$. For remaining 19 samples, the average bacteria count was 5.3 MPN/ml. Escherichia coli was isolated from 11 (22\%) of the samples. Mean acidity, fat and dry matter contents of kefir samples were found as 0.8 L.A.\%, $2.3 \%$ and $11.3 \%$, respectively, while the pH values varied between 3.9 and 4.7 . Consequently, the microbiological findings showed the contamination of kefir samples with microorganisms including E. coli and $S$. aureus, well known as a remarkable bacterial pathogens, and thus possible health risks for consumers.
\end{abstract}

Key words: Chemical characteristic, kefir, microorganism and pathogen bacteria.

\section{Bursa'da tüketime sunulan kefirlerin mikrobiyolojik ve kimyasal özelliklerinin belirlenmesi}

Özet: Çalı̧̧ma, Bursa ilindeki farklı perakende satış yerlerinden satın alınan 50 adet kefir örneğinin mikrobiyolojik kalitesini ve bazı kimyasal özelliklerini belirlemek amacıyla gerçekleştirildi. İncelenen örneklerde laktobasil, laktokok, enterokok, enterobakteri, Staphylococcus aureus ve maya sayllar1 sirasiyla ortalama $3.6 \times 10^{7} \mathrm{kob} / \mathrm{ml}, 1.8 \times 10^{8} \mathrm{kob} / \mathrm{ml}, 4.8 \times 10^{4} \mathrm{kob} / \mathrm{ml}, 7.3 \times 10^{3}$ $\mathrm{kob} / \mathrm{ml}, 2.4 \times 10^{2} \mathrm{kob} / \mathrm{ml}$ ve $7.7 \times 10^{4} \mathrm{kob} / \mathrm{ml}$ olarak belirlendi. 50 kefir örneğinden 26 'sının $<0.30 \mathrm{MPN} / \mathrm{ml}$ düzeyinde, buna karşılık 5 örneğin >110 MPN/ml seviyelerinde koliform bakterileri içerdiği tespit edildi. Kalan 19 örnekte ise, ortalama bakteri sayıs1 5.3 MPN/ml'ydi. Örneklerin 11'inden (\% 22) Escherichia coli izole edildi. Kefir örneklerinde pH değerleri 3.9 ve 4.7 arasında değişirken; ortalama asitlik, yağ ve kurumadde içeriklerinin sırasıyla \%0.8 L.A., \%2.3 ve \%11.3 olduğu tespit edildi. Sonuç olarak, mikrobiyolojik bulgular kefir örneklerinin önemli bakteriyel patojenler arasında yer alan E. coli ve $S$. aureus gibi mikroorganizmalarla kontamine olduğunu ve dolayısıyla tüketiciye yönelik olası sağlık risklerini ortaya koydu.

Anahtar sözcükler: Kefir, kimyasal özellik, mikroorganizma ve patojen bakteri.

\section{Introduction}

Fermented milks or beverages made with cocultures of lactic acid bacteria and yeasts are widely produced in many countries in the region between Eastern and Mongolia. Some typical examples are acidophilin, kefir and koumiss (2). Kefir is a natural probiotic containing live bacteria, yeasts and the products that these microorganisms produce (22), and has a sharp acidic taste and yeasty flavour (13).

The beverage is commonly manufactured by fermenting milk with kefir grains by a complex microbial symbiotic mixture of bacteria Lactobacillus, Lactococcus, Leuconostoc and Streptococcus, and yeasts Kluyveromyces, Torula and Saccharomyces $(11,14)$. So that according to Turkish Food Codex, kefir is defined as the product in potable consistency, obtained by fermentation of milk by kefir grains containing lactic acid bacteria, acetic acid bacteria and Torula yeast (18).
Kefir can be produced by fermenting milk with commercial freeze-dried kefir starter cultures or traditional kefir grains (2). The grains are insoluble in water and irregular in shape and size varying from 0.3$3.5 \mathrm{~cm}$ in diameter $(3,16)$. The product is mainly produced from bovine milk as well as caprine and sheep milks $(2,4)$. For traditional kefir production, kefir grains are added to cow's milk in a 1:20 ratio, and left to ferment at $18-20^{\circ} \mathrm{C}$ for about $20 \mathrm{~h}$. At the end of the fermentation, the kefir grains are retrieved by sieving and re-used for new fermentations (7).

Lactobacilli are present as the largest portion (65$80 \%$ ) of the microbial population, with lactococci and yeasts making up the remaining portion of the microbes present in the kefir grain (20). Both the bacteria and yeasts are surrounded by a polysaccharide matrix, called kefiran, which is a water-soluble branched glucogalactan, and which has been reported to possess antibacterial, 
antimycotic and antitumor activity (12). In in vitro tests with cell-free extracts of kefir, the growth of Staphylococcus aureus, Bacillus cereus, Escherichia coli, Clostridium tyrobutyricum and Listeria monocytogenes was inhibited. In general, the antimicrobial activity of the beverage is atributed to lactic acid, volatile acids, hydrogen peroxide, carbondioxide, diacetyl, acetaldehyde, and/or bacteriocins produced by LAB (16). Yeasts are also important in kefir fermentation because of the production of ethanol and carbondioxide. Kefir grains usually contain lactose-fermenting yeasts (Kluyveromyces lactis, Kluyveromyces marxianus, Torula kefir), as well as nonlactose-fermenting yeasts (Saccharomyces cerevisiae) (10).

The microbial community composition of kefir can change by several factors such as the source and microbial load of the grains, the fermentation process, and storage conditions $(4,5,16)$. The aim of this study was to evaluate the microbiological quality and physicochemical characteristics of kefir samples sold in Bursa province and to manifest health hazards for the consumer.

\section{Materials and Methods}

Samples: A total of 50 kefir samples were collected from different retail markets in Bursa province (Turkey). The samples were transported to the laboratory under refrigerated conditions, and all analyses were carried out on the same day.

Microbiological analysis: $10 \mathrm{ml}$ of the kefir samples were homogenized with $90 \mathrm{ml}$ of a sterile $0.1 \%$ peptone water solution using a Lab-Blender 80 Stomacher (London, UK) for at least $2 \mathrm{~min}$. Serial dilutions of the homogenate were made with sterile peptone water and plated in duplicates on specific media. Lactobacilli counts were performed on deMan Rogosa and Sharpe medium (MRS, Oxoid CM361) at incubation temperature of $30^{\circ} \mathrm{C}$ under anaerobic conditions $\left(5 \% \mathrm{CO}_{2}\right)$ for 3 days. Lactococci counts were carried out on M17 medium (Oxoid CM785) at incubation of $30^{\circ} \mathrm{C}$ under anaerobic conditions for 2 days (10). Dilutions were plated on Slanetz-Bartley (SB, Oxoid CM377) and Violet Red Bile Glucose (VRBG, Oxoid CM485) mediums for enterococci and Enterobacteriaceae, respectively. Plates were incubated aerobically at $37^{\circ} \mathrm{C}$ for $24-48 \mathrm{~h}$. Yeasts were enumerated in Potato Dextrose Agar (PDA, Oxoid CM139) (pH 3.5) with $10 \%$ added tartaric acid, after incubation at $22^{\circ} \mathrm{C}$ for 5 days. S. aureus cultures was grown on Baird Parker agar (Oxoid CM0275) supplemented with egg yolk-tellurite emulsion (Merck 1.03785 ) at $35^{\circ} \mathrm{C}$ for $48 \mathrm{~h}$. The coagulase activity was performed by using Staphaurex test (Remel ZL30) (9). Total coliform counts were determined by the standard most probable number (MPN) method (19). Lauryl Sulphate Tryptose Broth (Oxoid CM451) containing Durham's tube was used as the media for presumptive test. $10 \mathrm{ml}, 1 \mathrm{ml}$ and $0.1 \mathrm{ml}$ of aliquots sample was inoculated into 3 Lauryl Sulphate Tryptose tubes and all tubes were incubated at $37^{\circ} \mathrm{C}$ for 24 to $48 \mathrm{~h}$. Any gas formation in Durham's tubes with slight turbidity in the medium was regarded as positive and coliform numbers were estimated using the MPN tables to determine the MPN index per millilitre. For the determination of $E$. coli, a loopful from each positive Lauryl Sulphate Tryptose tube was streaked on Eosin Methylene Blue agar (EMB, Oxoid CM69) and incubated at $37^{\circ} \mathrm{C}$ for 24$48 \mathrm{~h}$. Suspicious colonies (dark centered with or without a green metallic sheen) of E. coli on EMB agar were subjected to confirmation tests (IMVIC). Indole (+), methyl red $(+)$, Voges Proskauer $(-)$ and citrate $(-)$ cultures after 24 to $48 \mathrm{~h}$ incubation at $37^{\circ} \mathrm{C}$ were assessed as $E$. coli type 1 .

Physicochemical analysis: For $\mathrm{pH}$ measurements, a Mettler Toledo $\mathrm{pH}$ meter with a glass electrode was used. The acidity was determined by titration with $\mathrm{N} / 10 \mathrm{NaOH}$ in the presence of phenolphthalein and expressed as per cent lactic acid (LA). The total fat and dry matter contents in kefir samples were performed according to Tekinsen et al. (17).

\section{Results}

Lactobacilli, lactococci, enterococci, Enterobacteriaceae, $S$. aureus and yeast counts obtained from kefir samples and frequency distribution are presented in Table 1 and Table 2, respectively. Table 3 summarizes the results obtained for coliform bacteria in this study. The $\mathrm{pH}$ values and some chemical characteristics of kefir are shown in Table 4.

Table 1. Mean counts (cfu/ml) of microorganisms in kefir samples

Tablo 1. Kefir örneklerindeki ortalama mikroorganizma sayıları (kob/ml)

\begin{tabular}{lllll}
\hline Microorganisms & Mean & SEM & Minimum & Maximum \\
\hline Lactobacilli & $3.6 \times 10^{7}$ & $1.4 \times 10^{7}$ & $1 \times 10^{1}$ & $5.9 \times 10^{8}$ \\
Lactococci & $1.8 \times 10^{8}$ & $2.1 \times 10^{7}$ & $1.0 \times 10^{5}$ & $6.3 \times 10^{8}$ \\
Enterococci & $4.8 \times 10^{4}$ & $2.6 \times 10^{4}$ & $<1 \times 10^{2}$ & $9.1 \times 10^{5}$ \\
Enterobacteriaceae & $7.3 \times 10^{3}$ & $7.2 \times 10^{3}$ & $<1 \times 10^{1}$ & $3.6 \times 10^{5}$ \\
S. aureus & $2.4 \times 10^{2}$ & $2.0 \times 10^{2}$ & $<1 \times 10^{2}$ & $1 \times 10^{4}$ \\
Yeast & $7.7 \times 10^{4}$ & $2.9 \times 10^{4}$ & $<1 \times 10^{2}$ & $1.1 \times 10^{6}$ \\
\hline
\end{tabular}


Table 2. The distribution of the microorganism counts (cfu/ml)

Tablo 2. Mikroorganizma sayılarının dağ 11 lımı (kob/ml)

\begin{tabular}{lllllllll}
\hline \multirow{2}{*}{ Microorganisms } & \multicolumn{9}{c}{ Contamination levels } \\
& $<10^{2}$ & $10^{2}$ & $10^{3}$ & $10^{4}$ & $10^{5}$ & $10^{6}$ & $10^{7}$ & $10^{8}$ \\
\hline Lactobacilli & $1(2)^{\mathrm{a}}$ & $2(4)$ & $3(6)$ & $8(16)$ & $6(12)$ & $10(20)$ & $15(30)$ & $5(10)$ \\
Lactococci & $0(0)$ & $0(0)$ & $0(0)$ & $0(0)$ & $5(10)$ & $6(12)$ & $20(40)$ & $19(38)$ \\
Enterococci & $33(66)$ & $4(8)$ & $3(6)$ & $7(14)$ & $3(6)$ & $0(0)$ & $0(0)$ & $0(0)$ \\
Enterobacteriaceae & $45(90)$ & $2(4)$ & $2(4)$ & $0(0)$ & $1(2)$ & $0(0)$ & $0(0)$ & $0(0)$ \\
S. aureus & $42(84)$ & $6(12)$ & $1(2)$ & $1(2)$ & $0(0)$ & $0(0)$ & $0(0)$ & $0(0)$ \\
Yeast & $33(66)$ & $1(2)$ & $3(6)$ & $5(10)$ & $7(14)$ & $1(2)$ & $0(0)$ & $0(0)$ \\
\hline
\end{tabular}

a:The number (\%) of samples in different population groups

Table 3. Analysis results for coliform bacteria

Tablo 3. Koliform bakterilere ilişkin analiz sonuçları

\begin{tabular}{|c|c|c|c|c|c|c|c|c|c|c|c|}
\hline \multicolumn{12}{|c|}{$\mathrm{MPN} / \mathrm{ml}$} \\
\hline$<0.30$ & 0.3 & 0.36 & 0.62 & 1.1 & 1.5 & 1.6 & 3.5 & 9.3 & 29 & 46 & $>110$ \\
\hline $26(52)^{\mathrm{a}}$ & $3(6)$ & $4(8)$ & $2(4)$ & $2(4)$ & $2(4)$ & $2(4)$ & $1(2)$ & $1(2)$ & $1(2)$ & $1(2)$ & $5(10)$ \\
\hline
\end{tabular}

a: the number of samples (\%)

Table 4. The physicochemical characteristics of kefir samples Tablo 4. Kefir örneklerinin fizikokimyasal özellikleri

\begin{tabular}{lccc}
\hline Parameter & Mean \pm SEM & Minimum & Maximum \\
\hline $\mathrm{pH}$ & $4.3 \pm 0.02$ & 3.9 & 4.7 \\
Acidity (L.A.), \% & $0.8 \pm 0.02$ & 0.7 & 1.4 \\
Dry matter, \% & $11.3 \pm 0.36$ & 8.0 & 16.5 \\
Fat, \% & $2.3 \pm 0.14$ & 0.3 & 4.5 \\
\hline
\end{tabular}

\section{Discussion and Conclusion}

As seen in Table 1 , the mean counts $\left(3.6 \times 10^{7}\right.$ $\mathrm{cfu} / \mathrm{ml}$ ) of lactobacilli in samples purchased from retail markets in Bursa were similar to Irigoyen et al. (10), Fontan et al. (6) and Witthuhn et al. (20) These authors found counts of $8 \mathrm{log} \mathrm{cfu} / \mathrm{ml}, 7.2 \mathrm{log} \mathrm{cfu} / \mathrm{ml}$ and $1.2 \times 10^{7}$ $\mathrm{cfu} / \mathrm{ml}$, respectively. The lactobacilli levels $(9.42 \mathrm{log}$ $\mathrm{cfu} / \mathrm{ml}$ and $8.33 \mathrm{log} \mathrm{cfu} / \mathrm{ml}$ ) detected by Gulmez et al. (8) and Dinc (4), respectively, were also higher than the ones described in this study. On the other hand, lower levels of lactobacilli (1.5 to $3.48 \mathrm{log} \mathrm{cfu} / \mathrm{ml}$ ) were obtained by Wszolek et al. (21) in experimental kefir samples.

In the present study, the mean counts of lactococci were $1.8 \times 10^{8} \mathrm{cfu} / \mathrm{ml}$ (Table 1). Similar results were reported by Irigoyen et al. (10) and Fontan et al. (6) who found the mean counts of lactococci as $8 \mathrm{log} \mathrm{cfu} / \mathrm{ml}$ and $7.8 \mathrm{log} \mathrm{cfu} / \mathrm{ml}$, respectively. On the other hand, lower or higher values of lactococci loads than that of the current work have been suggested by other some authors in kefir. Wszolek et al. (21) examined kefir samples made from ovine milk using kefir grains in Poland and detected counts of $9 \mathrm{log} \mathrm{cfu} / \mathrm{ml}$. Witthuhn et al. (20) obtained counts of $1.2 \times 10^{7} \mathrm{cfu} / \mathrm{ml}$ for lactococci in kefir grains after 20 day of traditional kefir production.
In this investigation, enterococci and Enterobacteriaceae were found in $34 \%$ and $10 \%$ of the samples, with mean counts of $4.8 \times 10^{4}$ and $7.3 \times 10^{3} \mathrm{cfu} / \mathrm{ml}$, respectively. The results are illustrated in Table 1 . A study conducted by Dinc (4) suggested that average counts of enterococci and Enterobacteriaceae in 120 kefir samples purchased from supermarkets in Ankara were $2.5 \log \mathrm{cfu} / \mathrm{ml}$ and $2.1 \mathrm{log} \mathrm{cfu} / \mathrm{ml}$, respectively. These levels of contamination were lower than those obtained in our study. In Poland, Molska et al. (15) recorded $29 \%$ and $17 \%$ of kefir samples harbored enterococci at levels of $10^{1}-10^{3} \mathrm{cfu} / \mathrm{ml}$ and $>10^{3} \mathrm{cfu} / \mathrm{ml}$, respectively.

Eight of kefir samples analysed were found positive for $S$ aureus ranging from $1 \times 10^{2}$ to $1 \times 10^{4} \mathrm{cfu} / \mathrm{ml}$, with a mean of $2.4 \times 10^{2} \mathrm{cfu} / \mathrm{ml}$ (Table 1). Among them, one isolate showed coagulase-positive activity and had counts of $2 \times 10^{2} \mathrm{cfu} / \mathrm{ml}$ (data not shown). The reason for the contamination of $S$. aureus could have been the poor personal hygiene of food handlers and inadequate control of cold temperatures.

In the present survey, the mean counts for yeast were $7.7 \times 10^{4} \mathrm{cfu} / \mathrm{ml}$ (Table 1). These results were similar to those obtained by Adamavičiūte et al. (1), Irigoyen et al. (10), Wszolek et al. (21) and Witthuhn et al. (20). They found yeast counts of $4.2 \mathrm{log} \mathrm{cfu} / \mathrm{ml}, 5 \mathrm{log} \mathrm{cfu} / \mathrm{ml}$, $4.8 \mathrm{log} \mathrm{cfu} / \mathrm{ml}$ and $4.6 \mathrm{cfu} / \mathrm{ml}$, respectively. However, our results were lower than those found by Gulmez et al. (8) in kefir $9.4 \log \mathrm{cfu} / \mathrm{ml}$, and were higher than those ( 3 to $3.9 \log \mathrm{cfu} / \mathrm{ml}$ ) reported by other some authors $(4,6)$. In Turkey, Turkish Food Codex established a guideline with a minimum level of $10^{4} \mathrm{cfu} / \mathrm{ml}$ for yeast (18). According to our results, the counts of yeast were below the 
detectable limit $\left(<10^{2} \mathrm{cfu} / \mathrm{ml}\right)$ in 33 samples and between $10^{2}-<10^{4} \mathrm{cfu} / \mathrm{ml}$ in 4 samples. On the basis of this guideline, a total $(74 \%)$ of 37 kefir samples were regarded as being of unsatisfactory quality.

The contamination levels with coliform bacteria of 26 samples were $<0.30 \mathrm{MPN} / \mathrm{ml}$ and 5 samples were found to be contaminated at levels of $>110 \mathrm{MPN} / \mathrm{ml}$. For remaining 19 samples, coliform counts were in the range of 0.3 to $46 \mathrm{MPN} / \mathrm{ml}$, with an average of $5.3 \mathrm{MPN} / \mathrm{ml}$ (Table 3). This finding does not agree with that of Wszolek et al. (21) suggesting the absence of coliform bacteria. Another study (4) of kefir samples on retail sale in Turkey (Ankara) carried out between December 2006 and May 2007, indicated that the samples contained coliforms with mean contamination level of 11.58 $\mathrm{MPN} / \mathrm{ml}$, which is higher than a mean coliform count reported here. According to Turkish Food Codex, pathogen microorganisms should not be detected in kefir as well as other cultured dairy products (18). In this investigation, the incidence of $E$. coli was $22 \%(11 / 50)$ in the samples, which is close to the incidence (25\%) reported by Dinc (4). The presence of coliforms including $E$. coli in samples is often an indication of contamination during production, which can occur from poor hygienic conditions.

Table 4 shows the values of the main physicochemical parameters in kefir samples. The samples had a $\mathrm{pH}$ value between 3.9 and 4.7 , with a mean 4.3. This finding was similar to values observed in kefir by other some workers $(4,6,10,15)$. However, higher values than ours (as high as 9.5) were found by Gulmez et al. (8). The values of titratable acidity in the current study were a mean of $0.8 \%$ L.A, ranging from $0.7 \%$ to $1.4 \%$ L.A. These values were consistent with the limit (min. $0.6 \%$ L.A.) laid down in Turkish Food Codex, and also similar to those noted by Dinc (4) and by Fontan et al. (6), who found an average of $2.7 \%$ L.A. and $1.32 \%$ L.A., respectively, in kefir. The fat and dry matter values of kefir samples analysed in this work ranged from 0.3 to $4.5 \%$ and 8.0 to $16.5 \%$, respectively. Other published studies also reported similar results. Irigoyen et al. (10) indicated the fat and dry matter contents of 3.2-3.59\% and 11.3-11.6\%, respectively, in kefir samples made using the $1 \%$ and $5 \%$ kefir grains. Dinc (4) demonstrated the mean values of $2.7 \%$ and $13.3 \%$ for fat and dry matter contents, respectively.

In conclusion, the results of this work on the microbiological quality of kefir sold in Bursa province indicated the high levels of hygiene indicator bacteria such as coliforms and enterococci, or the presence of potential pathogenic bacteria such as E. coli and $S$. aureus. So that, approximately $38 \%$ of the samples failed to meet the legal requirements in terms of overall microbiological quality. Thus, these products are of unsatisfactory and/or unacceptable microbiological quality and there is reason to suspect possible public health concerns. Good hygienic practices should be applied throughout manufacture and at retail to ensure that contamination and pathogen growth do not occur in kefir.

\section{References}

1. Adamavičiūtė D, Stimbirys A, Sekmokienè D, Malakauskas M, Šernienè L (2006): Milk and kefir microbiological analysis. Vet Zootec, 36- 5-10.

2. Bensmira M, Nsabimana C, Jiang B (2010): Effects of fermentation conditions and homogenization pressure on the rheological properties of kefir. LWT-Food Sci Technol, 43, 1180-1184.

3. Çağındı Ö, Ötleş S (2003): Beslenme ve sağlık açısından kefirin önemi. Süt Endüstrisinde Yeni Eğilimler Sempozyumu (SEYES) Bildiriler Kitabı, 22-23 Mayıs 2003, İzmir, 371-374.

4. Dinç A (2008): Kefirin bazı mikrobiyolojik ve kimyasal özelliklerinin belirlenmesi. A.Ü. Sağlık Bilimleri Enstitüsü, Besin Hijyeni ve Teknolojisi Anabilim Dalı Yüksek Lisans Tezi, Ankara.

5. Ersoy M, Uysal H (2003): Süttozu, peyniraltı suyu tozu ve yayıkaltı karışımları ile üretilen kefirlerin özellikleri üzerine bir araştırma II. Bazı fiziksel ve duyusal özellikler. EÜ Ziraat Fak Derg, 40, 79-86.

6. Fontan MCG, Martinez S, Franco I, Carballo J (2006): Microbiological and chemical changes during the manufacture of kefir made from cow's milk, using a commercial starter culture. Int Dairy J, 16, 762-767.

7. Grønnevik H, Falstad M, Narvhus JA (2011): Microbiological and chemical properties of Norwegian kefir during storage. Int Dairy J, (in press).

8. Gulmez M, Cellesi F, Duman B, Tireli N (2009): Kefir içeceğinden starter veya probiyhotik kültür olarak kullanılabilecek immobilize (yapay) kefir tanesi üretmek. 3. Ulusal Veteriner Gıda Hijyeni Kongresi Özet Kitab1, 14-16 May1s 2009, Bursa, 77-85.

9. Harrigan WF (1998): Laboratory Methods in Food Microbiology. $3^{\text {rd }}$ Edition, Academic Press, London.

10. Irigoyen A, Arana I, Castiella M, Torre P, Ibanez FC (2005): Microbiological, physicochemical, and sensory characteristics of kefir during storage. Food Chem, 90, 613-620.

11. Jianzhong Z, Xiaoli L, Hanhu J, Mingsheng D (2009): Analysis of the microflora in Tibetan kefir grains using denaturing gradient gel electrophoresis. Food Microbiol, 26, 770-775.

12. Lee MY, Ahn KS, Kwon OK, Kim MJ, Kim MK, Lee IY, Oh SR, Lee HK (2007): Anti-inflammatory and antiallergic effects of kefir in a Mouse asthma model. Immun, 212, 647-654.

13. Magalhaes KT, Pereira GVM, Dias DR, Schwan RF (2010): Microbial communities and chemical changes during fermentation of sugary Brazilian kefir. World $\mathbf{J}$ Microbiol Biotechnol, 26, 1241-1250.

14. Miguel MGCP, Cardoso PG, Lago LA, Schwan RF (2010): Diversity of bacteria present in milk kefir grains 
using culture-dependent and culture-independent methods. Food Res Int, 43, 1523-1528.

15. Molska I, Nowosielska R, Frelik I (2003): Changes in microbiological quality of kefir and yoghurt on the Warsaw market in the years 1995-2001. Rocz Panstw Zakl Hig, 54, 145-152.

16. Powell JE, Witthuhn RC, Todorov SD, Dicks LMT (2007): Characterization of bacteriocin ST8KF produced by a kefir isolate Lactobacillus plantarum ST8KF. Int Dairy J, 17, 190-198.

17. Tekinşen OC, Atasever M, Keleş A (1997): Süt Ürünleri Üretimi ve Kontrolü. Selçuk Üniversitesi Basımevi, Mimoza Basım, Yayım ve Dağıtım A.Ş, Konya.

18. Turkish Food Codex (2001): Communiqué on Fermented Milk. Communication No. 2001/21, The Official Gazette 03.09.2001-24512, Ankara-Turkey.

19. Turkish Standard (1996): Microbiology-General Guidance for the Enumeration of Coliforms-Most Probable Number Technique. TS 7725 ISO 4831, ICS 07.100.30, Turkish Standard Institute, Ankara-Turkey.

20. Witthuhn RC, Schoeman T, Britz TJ (2005): Characterisation of the microbial population at different stages of kefir production and kefir grain mass cultivation. Int Dairy J, 15, 383-389.
21. Wszolek M, Tamime AY, Muir DD, Barclay MNI (2001): Properties of kefir made in Scotland and Poland using bovine, caprine and ovine milk with different starter cultures. Lebensm.-Wiss.u.-Technol, 34, 251-261.

22. Yuksekdag ZN, Beyatli Y, Aslim B (2004): Determination of some characteristics coccoid forms of lactic acid bacteria isolated from Turkish kefirs with natural probiotic. Lebensm.-Wiss.u.-Technol, 37, 663667.

Geliş tarihi: 14.09.2011 / Kabul tarihi: 10.01.2012

\author{
Address for correspondence: \\ Doç. Dr. Figen Çetinkaya \\ Uludağ Üniversitesi, Veteriner Fakültesi, \\ Besin Hijyeni ve Teknolojisi Anabilim Dall, \\ 16059 Görükle Kampüsü, Bursa. \\ Phone: +90 224 2941212, Fax: +90 2242941202. \\ E-mail:figcetinkaya@yahoo.com
}

